\title{
Comparative Antimicrobial Activity of Tea Tree Oil (Melaleuca Oil) and Common Topical Antimicrobials against Bacteria Associated With Wound and Topical Infections
}

\author{
Bhoj R Singh*, Prasanna Vadhana, Monika Bhardwaj, Vinodh Kumar OR, Dharmendra K Sinha and Shiv Varan Singh \\ Division of Epidemiology, Indian Veterinary Research Institute, Izatnagar-243 122, Uttar Pradesh, India \\ "Corresponding author: Bhoj R Singh, Division of Epidemiology, Indian Veterinary Research Institute, Izatnagar-243 122, Uttar Pradesh, India, Tel: +91-8449033222; E- \\ mail: brs1762@gmail.com
}

Received date: October 29, 2016; Accepted date: November 07, 2016; Published date: November 10, 2016

Copyright: () 2016 Singh BR, et al. This is an open-access article distributed under the terms of the Creative Commons Attribution License, which permits unrestricted use, distribution, and reproduction in any medium, provided the original author and source are credited.

\begin{abstract}
Tea Tree Oil (TTO) is a popular herbal antimicrobial for topical application against many microbes. This study was conducted to determine a spectrum of antimicrobial activity of TTO against bacteria often associated with topical infections and wound infection in human and animals. A total of 550 strains of bacteria and one strain of Candida albicans were tested for their sensitivity to TTO and eight antibiotics including polymyxin B sulfate, gentamicin, nitrofurantoin, tetracycline, chloramphenicol, co-trimoxazole, ciprofloxacin, and novobiocin. Gentamicin was the most effective antibiotic followed by chloramphenicol, ciprofloxacin, nitrofurantoin and polymyxin B inhibiting $87.1 \%$, $84.8 \%, 76.8 \%, 75 \%$ and $72.8 \%$ strains, respectively. Tea tree oil (at $1 \mu \mathrm{L} / \mathrm{mL}$ ) could inhibit the growth of $20.5 \%$ strains. Except all strains of Streptobacillus, Sphingomonas, Cytophaga and Brahmnella, 71.4\% Brucella, 60\% Bordetella and $53.1 \%$ Aeromonas species (46.9\%), only a few strains of other genera were sensitive to TTO. Only $20.5 \%$ strains were sensitive to TTO and multiple drug resistance (MDR) was positively correlated to their resistance to TTO, as $50 \%, 25 \%, 12 \%, 6 \%$ and $5 \%$ of the strains resistant to $0,1-2,3-4,5-6$ and $7-8$ antimicrobial drugs, respectively were sensitive to TTO. Sensitivity of bacteria to TTO was positively correlated $(p, \leq 0.05)$ with their sensitivity to novobiocin $(r, 0.24)$, tetracycline $(r, 0.22)$, gentamicin $(r, 0.21)$, ciprofloxacin $(r, 0.17)$, nitrofurantoin $(r$, $0.16)$, and chloramphenicol $(r, 0.14)$ while correlation was insignificant $(p,>0.05)$ with sensitivity to co-trimoxazole $(r$, $0.10)$ and polymyxin $B(r, 0.12)$. Minimum inhibitory concentration (MIC) of TTO varied from $0.001 \%$ to $>0.512 \%(\mathrm{v} / \mathrm{v}$ ) for different strains. The study revealed that TTO is a broad-spectrum antimicrobial active on 26 out of 44 genera of bacteria is a less promising antimicrobial than antibiotics on MDR strains. The study concluded that resistance to TTO, antibiotics and other antimicrobials in bacteria of clinical origin go hand in hand.
\end{abstract}

Keywords: Wound infection; TTO; MDR; Drug resistance; Staphylococcus; Streptococcus; Escherichia coli; Pseudomonas; Serratia

\section{Introduction}

Tea Tree (Melaleuca alternifolia) Oil (TTO) or melaleuca oil is known since long for many medicinal uses [1]. It is a volatile essential oil obtained through steam distillation of the leaves and terminal branches of $M$. alternifolia. It is available globally and is used for its antimicrobial properties [2]. It is toxic on oral consumption and for injection but can be used for topical applications [3] however; studies revealed that TTO is not genotoxic in vitro in mammalian cells [4]. It is incorporated as the active ingredient in many topical formulations used for the treatment of cutaneous infections for controlling dandruff, acne, lice, herpes, and other skin infections [5]. After an elaborate study on 800 TTO samples [6] about 100 compounds are identified in TTO. Antibacterial activity of TTO has been reviewed $[1,2]$ and is reported to be broad-spectrum inhibiting bacteria of more than 20 genera. The minimum inhibitory concentration (MIC) of TTO for most of the susceptible bacteria has been reported ranging from $0.003 \%(\mathrm{v} / \mathrm{v})$ for Prevotella intermedia $[7,8]$ and maximum $>8 \%(\mathrm{v} / \mathrm{v})$ for Enterococcus faecalis strains [9]. A recent study on ATCC reference and clinical strains [10] of different bacteria (Pseudomonas aeruginosa, Staphylococcus aureus, E. faecalis, Salmonella Enteritidis,
S. Typhimurium, Escherichia coli, Klebsiella pneumoniae) reported MIC of TTO $\leq 0.5 \%$ (v/v) for all $P$. aeruginosa strains (4\%, v/v).

Tea tree oil is bacteriostatic in low concentration but bactericidal at higher concentrations. Though exact mechanism of action is yet to be lucid it is hypothesized and proved to some extent $[11,12]$ that TTO act through increasing permeability of liposomal systems causing lysis and the loss of membrane integrity and manifested by the leakage of ions and the inhibition of respiration and ultimately death of the bacterium [13].

In early studies on the antimicrobial activity of TTO, it was hypothesized to be more active against antibiotic-resistant bacteria [14] thus attracted considerable interest. Thereafter, several studies were conducted but only on a limited number of strains specifically using mupirocin-resistant and methicillin-resistant strains of Staphylococcus aureus (MRSA) and of other bacteria [15-17]. Most of the studies concluded an insignificant difference in TTO sensitivity of antibiotic-resistant and sensitive strains [1]. Resistance to TTO in clinical isolates has not yet been reported and resistance of bacteria to conventional antibiotics has not been correlated with susceptibility to TTO [1], suggesting that cross-resistance does not occur. Tea tree oil is seen as important alternatives as a topical antimicrobial for antibiotics. Search for "alternatives to antibiotics" is identified as one of the most important goals to combat the emerging antibiotic resistant pathogens [18]. It is often claimed that TTO can replace antibiotics at least for topical applications $[1,19]$. The present study aimed to test the 
Citation: Singh BR, Vadhana P, Bhardwaj M, Vinodh Kumar OR, Sinha DK, et al. (2016) Comparative Antimicrobial Activity of Tea Tree Oil (Melaleuca Oil) and Common Topical Antimicrobials against Bacteria Associated With Wound and Topical Infections. Pharm Anal Acta 7: 513. doi:10.4172/2153-2435.1000513

Page 2 of 9

sensitivity of variety and number of the bacterial strain, isolated from clinical cases with the potential to cause a wound or cutaneous infections, to TTO and simultaneously to common use topical antimicrobials. Data was analyzed for correlation and association between TTO sensitivity and antimicrobial sensitivity and multi-drug resistance (MDR) in different bacteria of diverse origin.

\section{Materials and Methods}

Tea tree oil: Pure TTO (CAS Number 68647-73-4) purchased from Sigma-Aldrich (USA) was used in the study for determining its antibacterial activity.

Bacterial strains: A total of 550 strains of bacteria, belonging to 44 genera (Table 1) and one Candida albicans strain, isolated from clinical samples of patient (Table 2) buffaloes (45), cattle (111), deer (16), dogs (87), elephants (4), fish (12), goats (5), human (39), mithun (Bos frontalis, 10), pigs (76), poultry (4), swamp buffaloes (38), and tigers (12) including 11 reference strains available in glycerol stocks at Epidemiology Laboratory of ICAR-Indian Veterinary Research Institute, Izatnagar were revived and maintained on brain heart infusion agar (BD Difco) slants throughout the study at $4-8^{\circ} \mathrm{C}$ in refrigerator [20]. The reference strains included Enterobacter agglomerans (Ravi), Salmonella enterica ssp. enterica serovar Abortusequi (E-155 and E-156), Escherichia coli (E 382), Staphylococcus aureus (Cocci-7), Streptococcus milleri (SFB), Brucella abortus strain 19 (S-19 and S-19B), Brucella abortus (S-99), Listeria monocytogenes (MTCC-839), and Salmonella enterica ssp. enterica serovar Gallinarum (E-79).

\begin{tabular}{|c|c|c|c|c|}
\hline $\begin{array}{l}\text { Genus of bacteria (strains tested } \\
\text { in the study) }\end{array}$ & $\begin{array}{l}\text { Species of bacteria tested and number of strains tested for } \\
\text { sensitivity to TTO and other antimicrobials }\end{array}$ & $\begin{array}{l}\text { Tested for } \\
\text { MIC }\end{array}$ & $\begin{array}{l}\text { MIC range in } \\
\mathrm{nL} / \mathrm{mL}\end{array}$ & $\begin{array}{l}\text { Strains with minimum and } \\
\text { maximum MIC }\end{array}$ \\
\hline Achromobacter (1) & A. xylosoxidans 1 & 1 & $>5120$ & A. xylosoxidans \\
\hline Acinetobacter (8) & A. bowmanni 1, A. haemolyticus 1, A. Iwoffii 5, A. schindleri 1 & 1 & 10 & A. Iwoffii \\
\hline Actinobacillus (2) & A. actinomycetencomitans $1, A$. equeli 1 & 0 & 0 & \\
\hline Actinomyces (1) & A. pyogenes 1 & 0 & 0 & \\
\hline Aerococcus (2) & A. sanguinicola 2 & 0 & 0 & \\
\hline Aeromonas (32) & $\begin{array}{l}\text { A. bestiarum } 6, \text { A. caviae } 2, A \text {. eucranophila } 1, A \text {. hydrophila } 6 \text {, } \\
\text { A. media } 8, A \text {. salmonicida } 2, A \text {. schubertii } 2, A \text {. sobria } 2, A \text {. } \\
\text { veronii } 2\end{array}$ & 11 & $10->5120$ & $\begin{array}{l}\text { A. salmonicida } 10 \text { and } A . \\
\text { schuberti }>5120\end{array}$ \\
\hline Agrobacterium (1) & A. tumefaciens 1 & 0 & 0 & \\
\hline Alkaligenes (8) & A. denitrificans 4 , A. faecalis 4 & 0 & 0 & \\
\hline Bacillus (23) & $\begin{array}{l}\text { B. alvei } 1, B \text {. cereus } 3, \text { B. firmus } 2, \text { B. mycoides } 8, B . \\
\text { pentothenticus } 1, B . \text { polymyxa } 4, \quad B . \text { sphaericus } 1, \quad B . \\
\text { steriothermophilus } 1, \text { B. subtilis } 2\end{array}$ & 14 & $10->5120$ & $\begin{array}{l}\text { B. steariothermophilus } 10, B \text {. } \\
\text { plymyxa } 10->5120\end{array}$ \\
\hline Bordetella (5) & B. bronchiseptica 5 & 2 & $2560->5120$ & B. bronchiseptica \\
\hline Brahmnella (1) & B. cuniculi 1 & & & \\
\hline Brucella (21) & B. abortus 20, M. melitensis 1 & 5 & $10->5120$ & $\begin{array}{l}\text { B. abortus 10->5120, B. } \\
\text { melitensis } 2560\end{array}$ \\
\hline Budvicia (1) & B. aquatic 1 & 0 & 0 & \\
\hline Burkholderia (4) & B. pseudomallei 4 & 1 & $>5120$ & B. pseudomallei \\
\hline Candida (1) & C. albicans 1 & 1 & $>5120$ & C. albicans \\
\hline Citrobacter (5) & C. freundii 5 & 0 & 0 & \\
\hline Cytophaga (1) & C. columnaris 1 & 1 & 40 & C. columnaris \\
\hline Dermatophilus (2) & D. congolensis 2 & 2 & 40 & D. congolensis \\
\hline Edwardsiella (5) & E. tarda 4, E. hoshiniae 1 & 4 & $640->5120$ & $\begin{array}{l}\text { E. hoshiniae }>5120 \text {, E. tarda } \\
640->5120\end{array}$ \\
\hline Enterobacter (26) & $\begin{array}{l}\text { E. agglomerans } 22, E \text {. amnigenus } 1, E . \text { canerogenus } 1, E . \\
\text { gregoviae } 1, E \text {. intermedius } 1\end{array}$ & 1 & 10 & E. agglomerans \\
\hline Enterococcus (9) & $\begin{array}{l}\text { E. avium } 1 \text {, E. durans } 1 \text {, E. faecalis } 3 \text {, E. raffinosus } 2, E \text {. } \\
\text { solitarius } 2\end{array}$ & 1 & 640 & E. faecalis \\
\hline Erwinia (10) & $\begin{array}{l}\text { E. amylovora 4, E. carotovora 2, E. chrysanthemi 3, E. } \\
\text { tracheiphila } 1\end{array}$ & 2 & $640->5120$ & $\begin{array}{l}\text { E, carotovora } 640, \quad E . \\
\text { chrysanthemii }>5120\end{array}$ \\
\hline
\end{tabular}


Citation: Singh BR, Vadhana P, Bhardwaj M, Vinodh Kumar OR, Sinha DK, et al. (2016) Comparative Antimicrobial Activity of Tea Tree Oil (Melaleuca Oil) and Common Topical Antimicrobials against Bacteria Associated With Wound and Topical Infections. Pharm Anal Acta 7: 513. doi:10.4172/2153-2435.1000513

Page 3 of 9

\begin{tabular}{|c|c|c|c|c|}
\hline Escherichia (108) & E. coli 103 , E. fergusonii 4, E. vulneris 1 & 11 & $10->5120$ & $\begin{array}{l}\text { E. coli } 10->5120, \quad \text { E. } \\
\text { fergusonii } 5120\end{array}$ \\
\hline Hafnia (3) & H. alvei 3 & 0 & 0 & \\
\hline Klebsiella (21) & K. oxytoca 3, K. pneumoniae 18 & 1 & 320 & \\
\hline Leminorella (1) & L. ghrimontii 1 & 0 & 0 & \\
\hline Listeria (1) & L. monocytogenes 1 & 1 & 5120 & L. monocytogenes \\
\hline Microccus (7) & M. varians 7 & 1 & 2560 & M. varians \\
\hline Moraxella (13) & $\begin{array}{l}\text { M. atlantae } 4, M . \text { canis } 2, M . \text { non liquifaciens } 2, M . \text { osloensis } 3 \text {, } \\
\text { M. phenylpyruvica } 2\end{array}$ & 5 & $640->5120$ & $\begin{array}{l}\text { M. nonliquifaciens } 1280- \\
>5120, \quad M . \quad \text { osloensis } \\
640-5120\end{array}$ \\
\hline Morganella (1) & M. morganii 1 & 1 & $>5120$ & M. morganii \\
\hline Pasteurella (8) & P. canis 3, P. multocida 5 & 6 & $10->5120$ & $\begin{array}{l}\text { P. canis 10, P. multocida 10- } \\
>5120\end{array}$ \\
\hline Plesiomonas (5) & P. shigelloides 5 & 0 & 0 & \\
\hline Pragia (1) & P. fontium 1 & 0 & 0 & \\
\hline Proteus (22) & P. mirabilis 17, P. penneri 2, P. vulgaris 3 & 3 & $320->5120$ & $\begin{array}{l}P . \quad \text { mirabilis } 320-2560, \quad P . \\
\text { penneri }>5120\end{array}$ \\
\hline Providencia (1) & P. stuartii 1 & 0 & 0 & \\
\hline Pseudomonas (49) & $\begin{array}{l}P . \text { aeruginosa } 29, P . \text { alcaligenes } 1, P . \text { fluorescens } 6, P . \\
\text { paucibacillus } 5, P . \text { pseudoalcaligenes } 7, P . \text { vesicularis } 1\end{array}$ & 8 & $10->5120$ & $\begin{array}{l}P . \quad \text { vesicularis } \quad 10, \quad P . \\
\text { fluorescens, } P . \\
>5120\end{array}$ \\
\hline Raoultella (6) & R. terrigena 6 & 3 & $5120->5120$ & R. terrigena \\
\hline Salmonella (11) & $\begin{array}{l}\text { S. Gallinarum 1, S. Abortusequi 2, S. Adelaide 1, S. Kentucky } \\
\text { 3, S. Typhimurium } 4\end{array}$ & 7 & $160->5120$ & $\begin{array}{lr}\text { Serovar Gallinarum } & 1280 \\
\text { Abortusequi } & 1280, \\
\text { Typhimurium } 160->5120\end{array}$ \\
\hline Serratia (4) & S. marcescens 1 , S. odorifera 3 & 3 & 1280 & S. marcescens, S. odorifera \\
\hline Sphingomonas (1) & S. echinoides 1 & 1 & 320 & S. echinoides \\
\hline Staphylococcus (59) & 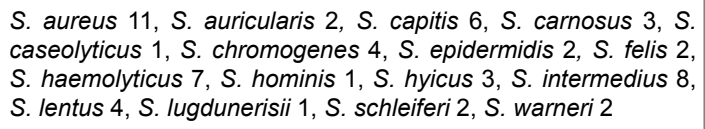 & 14 & $10->5120$ & $\begin{array}{l}\text { S. aureus 20->5120, S. } \\
\text { haemolyticus } 10->5120\end{array}$ \\
\hline Streptobacillus (1) & S. moniliformis 1 & 1 & 10 & \\
\hline Streptococcus (50) & $\begin{array}{l}\text { S. adjacens } 1, S \text {. agalactiae } 2, S \text {. bovis } 7, S \text {. canis } 1, S . \\
\text { defectivus } 2, S \text {. dysgalactiae } 1, S \text {. equi } 8, S \text {. faecalis } 1, S . \\
\text { milleri } 12, S \text {. porcinus } 2, S \text {. pyogenes } 12, S \text {. suis } 1\end{array}$ & 16 & $10->5120$ & S. equi 10 , S. canis $>5120$ \\
\hline Vibrio (6) & V. alginolyticus $2, V$. anguilarus $2, V$. choleare $1, V$. mimicus 1 & 1 & $>5120$ & V. choleare \\
\hline Xenorhabdus (3) & X. bovienii $1, X$. poinarii 2 & 0 & 0 & \\
\hline Total & About 128 species of 45 genera 551 & 131 & \multicolumn{2}{|l|}{$10->5120$} \\
\hline
\end{tabular}

Table 1: Minimum inhibitory concentration (MIC) of tea tree oil (TTO) for strains of different bacteria of clinical importance.

Antimicrobial sensitivity assay for TTO and antimicrobials: All the 551 strains were tested in triplicate for their sensitivity to TTO and 8 other antimicrobials using disc diffusion assay [21,22] on MuellerHinton agar (MHA, BD Difco) or $5 \%$ bovine serum supplemented MHA for slow growing and/ or fastidious bacteria (Streptococcus, Brucella, Bordetella, Brahmnella, Pasteurella, Listeria and Micrococcus species strains). Test plates were incubated at $37^{\circ} \mathrm{C}$ aerobically for $24 \mathrm{~h}$ except for Brucella (incubated in $5 \% \mathrm{CO}_{2}$ enriched environment, at $37^{\circ} \mathrm{C}$ for $48 \mathrm{~h}$ ). Discs of TTO were made to contain $2 \mu \mathrm{L}$ of oil using sterile $6 \mathrm{~mm}$ discs cut from Whatman filter paper no.3, discs of 8 of the topically applicable antibiotics including polymyxin B sulfate (50 IU), gentamicin $(30 \mu \mathrm{g})$, nitrofurantoin $(300 \mu \mathrm{g})$, tetracycline $(30 \mu \mathrm{g})$, chloramphenicol $(25 \mu \mathrm{g})$, co-trimoxazole $(25 \mu \mathrm{g})$, ciprofloxacin $(10 \mu \mathrm{g})$ and novobiocin $(5 \mu \mathrm{g})$ were procured from BD Difco. The maximum 
Citation: Singh BR, Vadhana P, Bhardwaj M, Vinodh Kumar OR, Sinha DK, et al. (2016) Comparative Antimicrobial Activity of Tea Tree Oil (Melaleuca Oil) and Common Topical Antimicrobials against Bacteria Associated With Wound and Topical Infections. Pharm Anal Acta 7: 513. doi:10.4172/2153-2435.1000513

Page 4 of 9

growth inhibition zones (in $\mathrm{mm}$ ) measured from the triplicate tests were recorded for each strain and entered into the Exel 2010 worksheet.

\begin{tabular}{|c|c|c|c|c|c|c|c|c|c|c|c|}
\hline \multirow[t]{2}{*}{ Source } & \multirow[t]{2}{*}{$\mathbf{N}$} & \multicolumn{9}{|c|}{ Number of bacteria resistant out of total number of bacteria tested } & \multirow[t]{2}{*}{ MDR strains } \\
\hline & & TTO & PB & G & Nit & $\mathbf{T}$ & C & Cot & Cip & $\mathbf{N b}$ & \\
\hline Buffalo & 48 & 38 & 10 & 6 & 5 & 5 & 4 & 11 & 8 & 38 & 10 \\
\hline Cattle & 111 & 91 & 17 & 9 & 36 & 31 & 14 & 36 & 11 & 93 & 36 \\
\hline Deer & 16 & 13 & 3 & 0 & 2 & 7 & 0 & 9 & 9 & 14 & 12 \\
\hline Dog & 87 & 68 & 31 & 17 & 24 & 29 & 18 & 43 & 29 & 48 & 35 \\
\hline Elephant & 4 & 4 & 0 & 0 & 0 & 0 & 0 & 0 & 0 & 4 & 0 \\
\hline Fish & 12 & 10 & 4 & 0 & 5 & 0 & 3 & 4 & 0 & 12 & 5 \\
\hline Goat & 5 & 5 & 2 & 0 & 0 & 1 & 0 & 0 & 0 & 3 & 0 \\
\hline Horse & 78 & 66 & 34 & 13 & 22 & 31 & 19 & 23 & 24 & 65 & 44 \\
\hline Human & 39 & 34 & 12 & 10 & 9 & 19 & 7 & 21 & 17 & 32 & 21 \\
\hline Mithun & 10 & 4 & 0 & 0 & 1 & 0 & 6 & 0 & 0 & 3 & 0 \\
\hline Pig & 76 & 57 & 24 & 11 & 18 & 30 & 10 & 41 & 19 & 59 & 38 \\
\hline Poultry & 4 & 3 & 2 & 0 & 2 & 2 & 0 & 0 & 0 & 4 & 2 \\
\hline Reference & 11 & 6 & 1 & 0 & 1 & 1 & 0 & 1 & 1 & 4 & 1 \\
\hline Swamp buffalo & 38 & 29 & 8 & 1 & 11 & 3 & 1 & 2 & 0 & 36 & 6 \\
\hline Tiger & 12 & 10 & 2 & 4 & 2 & 12 & 2 & 7 & 10 & 12 & 12 \\
\hline \multicolumn{2}{|c|}{ Total resistant $(n=551)$} & 438 & 150 & 71 & 138 & 171 & 84 & 198 & 128 & 427 & 218 \\
\hline \multicolumn{2}{|l|}{$\%$ Resistant } & 79.5 & 27.2 & 12.9 & 25.0 & 31.0 & 15.2 & 35.9 & 23.2 & 77.5 & 39.6 \\
\hline
\end{tabular}

Table 2: Source of bacteria and their resistance to different antimicrobials and tea tree oil. TTO, tea tree oil; PB, polymyxin B sulphate; G, gentamicin; Nit, nitrofurantoin; T, tetracycline; C, chloramphenicol; Cot, cotrimoxazole; Cip, ciprofloxacin; Nb, novobiocin, MDR, resistance to three of more antibiotics.

Determination of minimum inhibitory concentration (MIC) of TTO: Considering the findings of a recent study [10] that MIC of TTO for most of the bacteria is $\leq 0.5 \%(\mathrm{v} / \mathrm{v})$ a total of 130 strains of 31 genera (Table 1) were tested to determine MIC of TTO in triplicate using agar well dilution method [21] using TTO dilutions to achieve 10 to $5120 \mathrm{~nL}$ of $\mathrm{TTO} / \mathrm{mL}$ of medium. The growth medium and incubation procedures were the same as described for disc diffusion assay. After filling the wells (with $50 \mu \mathrm{L}$ of two-fold dilutions to contain $5120 \mathrm{~nL}$ to $10 \mathrm{~nL} /$ well) with the desired concentrations of TTO diluted in dimethyl sulfoxide (DMSO), plates were incubated without inversion for $1 \mathrm{~h}$ and then inverted for the required period of incubation. In each plate, one well filled with only DMSO was kept as control.

Statistical analysis: To determine a correlation between sensitivity (zone of growth inhibition in $\mathrm{mm}$ ) of test strains to TTO and other 8 antimicrobials correlation coefficient was calculated using MS Office Excel-7. To estimate the association between the sensitivity of bacteria of different types and of different sources to TTO and other antimicrobials, the $\chi^{2}$ test was performed in MS Office Excel-2007. The statistical analysis to compare in the $\chi^{2}$ test was done for those bacterial genera or sources only where the number (n) of strains tested was $\geq 10$.

\section{Results}

Of the 550 bacterial strains belonging to more than 124 species of 44 genera and (Table 1) $20.5 \%$ were sensitive to TTO. The only strain of $C$. albicans of human origin was resistant TTO. Of the bacteria tested, 397 and 153 strains were of Gram-positive (GPB, of 47 species of 10 genera) and Gram-negative bacteria (GNB, of more than 77 species of 34 genera), respectively. They could further be divided into oxidase positive (186) and oxidase negative (364) bacteria. Of the total tested strains $31,155,122$ and 242 strains were of oxidase positive GPB (OPGPB), oxidase positive GNB (OPGNB), oxidase negative GPB (ONGPB) and oxidase negative GNB (ONGNB), respectively. Of the tested strains of OPGPB, OPGNB, ONGPB and ONGNB, 71\%, 65.8\%, $84.4 \%$ and $86.8 \%$, respectively were resistant to TTO having no zone of inhibition around TTO discs in any of the three repeats of the test. There was no significant difference in sensitivity of GPB and GNB ( $p$, 0.4 ) strains to TTO. But oxidase positive strains were significantly more often ( $\mathrm{p},<0.001)$ sensitive to TTO than oxidase negative strains. More precisely, ONGNBs were significantly more often resistant to TTO than OPGPBs (p, 0.02), OPGNBs $(\mathrm{p},<0.01)$ but no significant difference was observed with strains of ONGPBs $(p,>0.5)$. However, 
Citation: Singh BR, Vadhana P, Bhardwaj M, Vinodh Kumar OR, Sinha DK, et al. (2016) Comparative Antimicrobial Activity of Tea Tree Oil (Melaleuca Oil) and Common Topical Antimicrobials against Bacteria Associated With Wound and Topical Infections. Pharm Anal Acta 7: 513. doi:10.4172/2153-2435.1000513

Page 5 of 9

more of OPGNBs were sensitive to TTO than ONGPBs (p, <0.01) Reference laboratory strains were more often sensitive to TTO than isolates from clinical samples either of human (p, 0.02) or of animal (p, $0.04)$ origin.

Of the tested microbes, $20.5 \%, 27.2 \%, 12.9 \%, 25 \%, 31 \%, 15.2 \%$, $35.9 \%, 23.2 \%$, and $77.5 \%$ were resistant to TTO, polymyxin B, gentamicin, nitrofurantoin, tetracycline, chloramphenicol, cotrimoxazole, ciprofloxacin and novobiocin, respectively (Table 3 ). Multiple drug resistance (resistance to three of more antibiotics, MDR) was present in $39.6 \%$ strains. Zone of growth inhibition by TTO was positively correlated ( $\mathrm{p}, \leq 0.05)$ with the zone of growth inhibition by novobiocin ( $r, 0.24)$, tetracycline $(r, 0.22)$, gentamicin $(r, 0.21)$, ciprofloxacin ( $r, 0.17)$, nitrofurantoin $(r, 0.16)$, and chloramphenicol ( $r$, $0.14)$ discs. However, the correlation was insignificant among TTO sensitivity and sensitivity to co-trimoxazole $(\mathrm{r}, 0.10)$ and polymyxin $\mathrm{B}$ $(\mathrm{r}, 0.12)$. Sensitivity to TTO had significant ( $\mathrm{p}, \leq 0.005)$ negative correlation $(\mathrm{r},-0.23)$ with MDR. All the bacterial strains having resistance to any one or more of the antibiotics were significantly more often ( $\mathrm{p},<0.01)$ resistant to TTO than those 32 strains sensitive to all the antimicrobials tested. Almost half of the strains sensitive to all the 8 antimicrobials were also sensitive to TTO, while only $25 \%, 12 \%, 6 \%$ and $5 \%$ of those resistant to $1-2,3-4,5-6$ and 7-8 antimicrobial drugs respectively were sensitive to TTO.

Of the strains of 44 genera of bacteria, none of the 47 strains of 18 genera was sensitive to TTO (Table 3) including strains of some common bacteria associated with topical and wound infections viz., strains of Acinetobacter, Actinobacillus, Actinomyces, Dermatophillus, Pasteurella and Serratia spp. On another hand, all the four strains, one each of Streptobacillus, Sphingomonas, Cytophaga and Brahmnella species were sensitive to TTO. More than $50 \%$ of the strains of other bacteria tested were resistant to TTO except Brucella (28.6\%), Bordetella (40\%) and Aeromonas (46.9\%) strains. The TTO was only little effective on the strains of the most common wound-infecting bacteria and bacteria causing topical skin infections including strains of Staphylococcus (19.9\%), Streptococcus (22\%), Pseudomonas (14.3\%), Escherichia coli (8.3\%) and Klebsiella (4.8\%) species.

\begin{tabular}{|c|c|c|c|c|c|c|c|c|c|c|}
\hline \multirow[t]{2}{*}{ Genus (Strains tested) } & \multicolumn{9}{|c|}{ Percent of strains resistant to the antimicrobials } & \multirow[t]{2}{*}{ MDR strains } \\
\hline & тто & PB & $\mathbf{G}$ & Nit & $\mathbf{T}$ & C & Cot & Cip & $\mathrm{Nb}$ & \\
\hline Achromobacter (1) & 1 & 0 & 0 & 0 & 0 & 0 & 0 & 0 & 0 & 0 \\
\hline Acinetobacter (8) & 6 & 3 & 1 & 5 & 1 & 1 & 2 & 0 & 7 & 3 \\
\hline Actinobacillus (2) & 2 & 0 & 0 & 1 & 0 & 0 & 1 & 0 & 2 & 0 \\
\hline Actinomyces (1) & 1 & 0 & 0 & 0 & 0 & 0 & 1 & 0 & 1 & 0 \\
\hline Aerococcus (2) & 2 & 0 & 0 & 1 & 0 & 0 & 0 & 1 & 1 & 0 \\
\hline Aeromonas (32) & 15 & 2 & 1 & 2 & 2 & 0 & 6 & 1 & 31 & 3 \\
\hline Agrobacterium (1) & 1 & 0 & 0 & 0 & 1 & 0 & 1 & 0 & 1 & 1 \\
\hline Alkaligenes (8) & 7 & 0 & 0 & 4 & 2 & 0 & 4 & 0 & 8 & 3 \\
\hline Bacillus (23) & 15 & 4 & 1 & 3 & 0 & 7 & 7 & 2 & 10 & 4 \\
\hline Bordetella (5) & 2 & 0 & 0 & 4 & 0 & 0 & 0 & 0 & 5 & 0 \\
\hline Brahmnella (1) & 0 & 1 & 0 & 0 & 0 & 0 & 0 & 0 & 1 & 0 \\
\hline Brucella (21) & 6 & 0 & 1 & 3 & 1 & 2 & 5 & 2 & 12 & 2 \\
\hline Budvicia (1) & 1 & 0 & 0 & 1 & 0 & 0 & 0 & 0 & 1 & 0 \\
\hline Burkholderia (4) & 3 & 4 & 0 & 4 & 0 & 4 & 0 & 0 & 4 & 4 \\
\hline Candia (1) & 1 & 1 & 1 & 1 & 1 & 1 & 1 & 1 & 1 & 1 \\
\hline Citrobacter (5) & 4 & 2 & 0 & 0 & 1 & 0 & 0 & 0 & 5 & 0 \\
\hline Cytophaga (1) & 0 & 0 & 0 & 1 & 0 & 0 & 1 & 0 & 1 & 1 \\
\hline Dermatophilus (2) & 2 & 1 & 0 & 0 & 0 & 0 & 0 & 0 & 2 & 0 \\
\hline Edwardsiella (5) & 4 & 0 & 1 & 0 & 1 & 0 & 1 & 0 & 5 & 1 \\
\hline Enterobacter (26) & 21 & 8 & 0 & 8 & 11 & 4 & 6 & 4 & 25 & 11 \\
\hline Enterococcus (9) & 9 & 6 & 7 & 2 & 4 & 4 & 5 & 5 & 7 & 7 \\
\hline Erwinia (10) & 7 & 2 & 0 & 1 & 3 & 0 & 2 & 1 & 10 & 4 \\
\hline Escherichia (108) & 99 & 18 & 17 & 12 & 56 & 11 & 50 & 43 & 108 & 56 \\
\hline
\end{tabular}


Citation: Singh BR, Vadhana P, Bhardwaj M, Vinodh Kumar OR, Sinha DK, et al. (2016) Comparative Antimicrobial Activity of Tea Tree Oil (Melaleuca Oil) and Common Topical Antimicrobials against Bacteria Associated With Wound and Topical Infections. Pharm Anal Acta 7: 513. doi:10.4172/2153-2435.1000513

Page 6 of 9

\begin{tabular}{|c|c|c|c|c|c|c|c|c|c|c|}
\hline Hafnia (3) & 3 & 0 & 0 & 1 & 1 & 0 & 1 & 1 & 3 & 1 \\
\hline Klebsiella (21) & 20 & 6 & 1 & 10 & 7 & 0 & 4 & 6 & 19 & 12 \\
\hline Leminorella (1) & 1 & 0 & 0 & 0 & 0 & 0 & 0 & 0 & 1 & 0 \\
\hline Listeria (1) & 1 & 0 & 0 & 0 & 0 & 0 & 0 & 0 & 0 & 0 \\
\hline Microccus (7) & 6 & 3 & 2 & 0 & 0 & 1 & 1 & 1 & 4 & 2 \\
\hline Moraxella (13) & 7 & 2 & 0 & 3 & 1 & 0 & 4 & 0 & 11 & 1 \\
\hline Morganella (1) & 1 & 0 & 0 & 1 & 0 & 0 & 1 & 0 & 1 & 1 \\
\hline Pasteurella (8) & 8 & 0 & 0 & 0 & 1 & 0 & 4 & 0 & 6 & 0 \\
\hline Plesiomonas (5) & 5 & 0 & 0 & 0 & 0 & 0 & 1 & 0 & 5 & 0 \\
\hline Pragia (1) & 1 & 0 & 0 & 0 & 0 & 0 & 0 & 0 & 1 & 0 \\
\hline Proteus (22) & 20 & 19 & 4 & 17 & 18 & 8 & 12 & 8 & 21 & 19 \\
\hline Providencia (1) & 1 & 1 & 0 & 1 & 1 & 0 & 0 & 0 & 1 & 1 \\
\hline Pseudomonas (49) & 42 & 7 & 6 & 36 & 27 & 31 & 31 & 10 & 44 & 35 \\
\hline Raoultella (6) & 5 & 1 & 1 & 3 & 2 & 1 & 1 & 1 & 6 & 2 \\
\hline Salmonella (11) & 6 & 0 & 0 & 0 & 3 & 0 & 0 & 3 & 10 & 3 \\
\hline Serratia (4) & 4 & 0 & 0 & 0 & 0 & 0 & 0 & 0 & 4 & 0 \\
\hline Sphingomonas (1) & 0 & 0 & 0 & 1 & 0 & 0 & 0 & 0 & 0 & 0 \\
\hline Staphylococcus (59) & 52 & 19 & 16 & 2 & 17 & 4 & 24 & 27 & 21 & 24 \\
\hline Streptobacillus (1) & 0 & 1 & 0 & 0 & 0 & 0 & 1 & 0 & 0 & 0 \\
\hline Streptococcus (50) & 39 & 36 & 11 & 9 & 9 & 5 & 20 & 11 & 13 & 15 \\
\hline Vibrio (6) & 4 & 3 & 0 & 1 & 0 & 0 & 0 & 0 & 5 & 1 \\
\hline Xenorhabdus (3) & 3 & 0 & 0 & 0 & 0 & 0 & 0 & 0 & 3 & 0 \\
\hline Total (551) & 438 & 150 & 71 & 138 & 171 & 84 & 198 & 128 & 427 & 218 \\
\hline$\%$ Resistant & 79.5 & 27.2 & 12.9 & 25.0 & 31.0 & 15.2 & 35.9 & 23.2 & 77.5 & 39.6 \\
\hline
\end{tabular}

Table 3: Tea tree oil and Antimicrobial drug resistance in bacteria isolated from clinical cases. TTO, tea tree oil; PB, polymyxin B sulphate; G, gentamicin; Nit, nitrofurantoin; T, tetracycline; C, chloramphenicol; Cot, cotrimoxazole; Cip, ciprofloxacin; Nb, novobiocin, MDR, resistance to three of more antibiotics.

On testing MIC of TTO on 130 strains of 31 genera of bacteria, the MIC was detected minimum $(10 \mathrm{~nL} / \mathrm{mL}, 0.001 \%$, v/v) for strains of Acienetobacter Iwoffii, Aeromonas salmonicida, Bacillus stearothermophilus, Enterobacter agglomerans, Escherichia coli, Pasteurella canis, P. multocida, Pseudomonas vesicularis, Staphylococcus haemolyticus, Streptobacillus moniliformis, and Streptococcus equi. The highest MIC of TTO $(>0.512 \%, \mathrm{v} / \mathrm{v})$ was observed in strains of Achromobacter xyloxidans, Aeromonas schubertii, Bacillus polymyxa, Bordetella bronchiseptica, Brucella abortus, Edwardsiella tarda, E. hoshiniae, Erwinia chrysanthemii, E. coli, E. fergusonii, Listeria monocytogenes, Moraxella nonliquifaciens, M. osloensis, Morganella morganii, Pasteurella multocida, Proteus penneri, Pseudomonas aeruginosa, Raoultella terrigena, Salmonella Typhimurium, Staphylococcus aureus, Streptococcus canis and Vibrio cholera. There were strains of the same bacterial species having TTO
MIC at both of the extremes viz., B. polymyxa, E. coli, and $P$. multocida.

No significant difference in sensitivity of GPBs and GNBs (p, 0.4) to TTO was seen. But oxidase positive strains were significantly more often ( $\mathrm{p},<0.001$ ) sensitive to TTO. Oxidase negative GNBs were significantly more often resistant to TTO than OPGPBs (p, 0.02), OPGNBs ( $\mathrm{p},<0.01)$ but the difference was insignificant with ONGPBs $(\mathrm{p},>0.5)$. More of OPGNBs were sensitive to TTO than ONGPBs ( $\mathrm{p}$, $<0.01)$. However, no difference between OPGPBs, ONGPBs ( $p,>0.08)$ was evident for TTO sensitivity.

Gram-positive bacteria were more often resistant to polymyxin B (p, $<0.001)$, gentamicin ( $p, 0.001)$ and ciprofloxacin $(\mathrm{p},<0.001)$ than GNBs but for nitrofurantoin, tetracycline and novobiocin the opposite were the observation ( $p, 0.001)$, and no significant difference in their sensitivity to chloramphenicol, co-trimoxazole and TTO (p, >0.4). 
Citation: Singh BR, Vadhana P, Bhardwaj M, Vinodh Kumar OR, Sinha DK, et al. (2016) Comparative Antimicrobial Activity of Tea Tree Oil (Melaleuca Oil) and Common Topical Antimicrobials against Bacteria Associated With Wound and Topical Infections. Pharm Anal Acta 7: 513. doi:10.4172/2153-2435.1000513

Page 7 of 9

Bacterial strains of human origin were more often resistant to gentamicin, tetracycline, co-trimoxazole and ciprofloxacin $(\mathrm{p},<0.02)$ than strains of animal origin. Similarly, oxidase positive strains were more often resistant to nitrofurantoin $(\mathrm{p},<0.01)$ than oxidase negative strains but more often sensitive to polymyxin B, gentamicin, tetracycline and ciprofloxacin $(\mathrm{p},<0.01)$. In general, irrespective of Gram staining, oxidase positive strains were more often resistant to chloramphenicol ( $p,<0.03$ ) but less to ciprofloxacin ( $p, \leq 0.03)$. For tetracycline, sensitivity didn't differ significantly among OPGPBs and ONGBPBs (p, 0.8), but GNBs were more often ( $p,<0.01)$ resistant to tetracycline irrespective of their oxidase activity. Oxidase activity and Gram reaction were significantly associated characters with resistance to polymyxin B ( $\mathrm{p},<0.01)$.

Results summarized in table 3 revealed that novobiocin was the least effective antibiotic on GNB $(\sim 7 \%)$ but quite good on GPBs $(>62 \%)$ with significant difference $(\mathrm{p},<0.01)$ among the two groups of bacteria. Among GNBs, E. coli (100\%) strains were the most resistant ones followed by aeromonads (97\%) and other Enterobacteriaceae members (90-96\%). There was no significant difference in sensitivity pattern of different GPBs to novobiocin $(\mathrm{p},>0.1)$.

Gentamicin, though the most effective (87.1\%) antibiotics on most of the bacterial strains were significantly less $(\mathrm{p},<0.05)$ effective on strains of Staphylococcus species strains than on other bacterial strains except those of E. coli, Proteus, Pseudomonas and Streptococcus species strains $(\mathrm{p},>0.05)$.

About $85 \%$ bacterial strains in the study were sensitive to chloramphenicol, strains of Bacillus $(<70 \%)$, Proteus $(<64 \%)$ and Pseudomonas $(<34 \%)$ species were significantly $(\mathrm{p}<0.03)$ more resistant than strains of other bacteria.

Ciprofloxacin, the 3rd most effective antibiotic ( 77\%) after gentamicin and chloramphenicol, was significantly $(\mathrm{p},<0.01)$ more effective on GNBs ( $80 \%)$ than GPBs ( 69\%). Among the GNBs, Proteus species $(>36 \%)$ and E. coli $(\sim 40 \%)$ strains were often more commonly ( $\mathrm{p},<0.05)$ resistant to ciprofloxacin.

Polymyxin B resistance was equally (p, 0.2) more common in strains of Proteus (p, <0.001) and Streptococcus spp. (p, <0.001) than in strains of other bacteria, irrespective of their staining or oxidase characteristics. Polymyxin B was more effective on strains of Brucella spp. (p, <0.05) than strains of other bacteria except Moraxella, Pseudomonas and Salmonella species (p, >0.06) strains.

Although nitrofurantoin inhibited about $75 \%$ strains of most of the bacteria, it was less effective on strains of Proteus (22.7\%)and Pseudomonas $(26.5 \%)$ than on strains of other bacteria ( $p,<0.04)$. Next in nitrofurantoin resistance were strains of Klebsiella (52.4\%) and Enterobacter (69.2\%) species.

Though more than $30 \%$ bacterial strains were resistant to tetracycline, strains of Aeromonas ( $p,<0.05)$, Bacillus ( $p,<0.01$ ), Brucella (p, <0.05) and Moraxella (p, <0.03) were more often sensitive than strains of other bacteria especially members of Enterobacteriaceae ( $>50 \%$ resistant).

Salmonellae were among the most sensitive strains (100\%) to cotrimoxazole while significantly $(\mathrm{p},<0.05)$ less number of Proteus (44.5\%), Pseudomonas (36.7\%) and Escherichia (53.7\%) and staphylococci and streptococci $(\sim 60 \%)$ strains were sensitive tor cotrimoxazole.

\section{Discussion}

Tea Tree oil is seen as potential oil to replace the use of antibiotics for topical use [19] and shown to inhibit many different types of bacteria $[1,5,10]$. However, in the present study on $>500$ strains of microbes of 45 genera, only $20.5 \%$ strains were sensitive to TTO, even less then the least effective antibiotic (novobiocin). The difference might be due to the fact that in the present study most of the strains included were of clinical origin while earlier studies are reported mostly on reference strains. In the present study too, reference strains were more often sensitive to TTO than those from clinical samples.

Multiple drug resistance (MDR) in bacterial strains and their sensitivity to TTO had strong $(\mathrm{p},<0.005)$ negative correlation $(\mathrm{r}$, -0.023 ), i.e., more the resistance to a number of antibiotics in bacteria more the chances of being them TTO resistant. In early studies, it was assumed that TTO was more active on antibiotic resistant bacteria, [14] which later on, were proved to be wrong assumptions [1]. The present study further proved the weakness of the present belief that resistance to antibiotic and sensitivity to TTO cannot be correlated $[1,17]$ and thus the mechanism of bacterial resistance to TTO may not be similar to antibiotic drug resistance. The sensitivity of bacteria to TTO was strongly $(\mathrm{p}, \leq 0.05)$ correlated with sensitivity to several antibiotics including novobiocin $(r, 0.24)$, tetracycline $(r, 0.22)$, gentamicin $(r, 0.21)$, ciprofloxacin $(r, 0.17)$, nitrofurantoin $(r, 0.16)$, and chloramphenicol $(r, 0.14)$. The strong correlation between TTO and antimicrobial sensitivity suggest that there may be a similarity in mechanism of action of antimicrobials and bacteria may also be employing a similar mechanism for defense against TTO as used against antibiotics. However, to prove the similarity between mechanism of action, and mechanism to resistance of TTO and antibiotics further studies are required. The variation observed from the earlier studies might be due to the inclusion of a large number of strains and clinical strains in the present study than in earlier studies on limited numbers and mostly the reference strains and diversity among the strains tested in different studies.

The MIC of TTO observed in the present study $(0.001 \%$ to $>0.512 \%$, $\mathrm{v} / \mathrm{v})$ was apparently similar to earlier observations $[7,9,10]$. However, some important differences observed might be due to number of strains included in the study, and strain diversity, as Andrade and coworkers [10] reported that for most of the Enterobacteriaceae and Enterococcus faecalis strains MIC of TTO was $\leq 0.5 \%(\mathrm{v} / \mathrm{v})$ while in the present study it ranged from $0.001 \%$ to $>0.512 \%$. In the same study [10], MIC of TTO for $P$. aeruginosa strains is reported $>4 \%$, in the present study too for all of the $P$. aeruginosa strains MIC was $>0.512 \%$. Another important observation was MIC of TTO $(<0.5 \%)$ for E. faecalis strains, in earlier studies it is reported either in similar range (Andrade et al., 2016) or much higher [9], indicating that source of strain might be an important determinant for sensitivity of bacteria to TTO. In total, sensitivity to TTO among strains of human origin and strains of animal origin not differed significantly ( $p, 0.025)$, but bacteria isolated from mithun (Bos frontalis) samples were significantly more often sensitive to TTO than in strains isolated from water buffalo (p, 0.01), deer (p, 0.03), dog (p, <0.01), fish (p, 0.04), horse (p, <0.01), human $(0,<0.01)$, pigs ( $\mathrm{p}, 0.02)$, swamp buffaloes ( $\mathrm{p}$, 0.03 ) and tigers (p, 0.04). The higher sensitivity of bacteria from mithuns might be due to no use of antibiotics in mithun due to their semi-domestic habitat and thus no resistance among bacteria of mithun origin [23].

Difference in sensitivity to TTO among strains of different origin observed in the present study further proved the same fact that origin 
Citation: Singh BR, Vadhana P, Bhardwaj M, Vinodh Kumar OR, Sinha DK, et al. (2016) Comparative Antimicrobial Activity of Tea Tree Oil (Melaleuca Oil) and Common Topical Antimicrobials against Bacteria Associated With Wound and Topical Infections. Pharm Anal Acta 7: 513. doi:10.4172/2153-2435.1000513

Page 8 of 9

of strains might be an important determinant for determining its sensitivity to TTO as reported earlier for other herbal drugs [21,24-29]. Similar sensitivity pattern of bacteria of mithun origin for other antimicrobials as to TTO, i.e., more commonly sensitive to other antimicrobials than strains of other origin further suggested the similar mechanism of emergence of resistance to antibiotics and TTO or probably for other herbal drugs too [29]. However, significantly ( $p$, $<0.02$ ) more common occurrence of resistance to chloramphenicol in strains of mithun origin than in microbes of other origin is unexplainable with the present study as it is the drug not at all used in animals especially in mithuns [22]. Resistance to chloramphenicol in the strains with no history of exposure of the drug might be due to the maintenance and circulation of the resistance gene even in naïve population and needs more studies to understand the phenomenon. More common occurrence of resistance in bacterial strains of human origin to gentamicin, tetracycline, co-trimoxazole and ciprofloxacin (p, $<0.02$ ) than in strains of animal origin, further proves that more and indiscriminate use of antibiotics might be associated with emergence of strains resistant to antibiotics [18,30-32]. Sensitivity of all the strains of Salmonella to cotrimoxazole might be an example to understand effect of discontinuation of an antimicrobial drug on getting rid of the emergence of antimicrobial drug resistance and support the policy advocating for controlling and minimizing the use of antimicrobials in therapeutics and for non-therapeutic purposes [18,30-32].

The study concludes that resistance to TTO, antibiotics and other antimicrobials in bacteria of clinical origin go hand in hand, and more hopes cannot be put on herbal antimicrobials to combat the threat of widespread antimicrobial drug resistant bacterial strains and emergence of more drug resistant strains. Though TTO inhibited the growth of wide range of bacteria proving it a broad spectrum antimicrobial potential, the study also revealed limitations of TTO as only one-fifth of clinical strains of bacteria were sensitive to it.

\section{Acknowledgement}

The authors are thankful to the Director and Joint Director (Research) and Joint Director (Academic) for supporting the study. We also thank My HC Joshi and Mr. Laiqurahman for consistent laboratory assistance.

\section{References}

1. Carson CF, Hammer KA, Riley TV (2006) Melaleuca alternifolia (Tea Tree) Oil: a review of antimicrobial and other medicinal properties. Clin Microbiol Rev 19: 50-62.

2. Carson CF, Riley TV (1993) Antimicrobial activity of the essential oil of Melaleuca alternifolia. Lett Appl Microbiol 16: 49-55.

3. Hammer KA, Carson CF, Riley TV, Nielsen JB (2006) A review of the toxicity of Melaleuca alternifolia (tea tree) oil. Food Chem Toxicol 44: 616-25.

4. Pereira TS, de Sant'Anna JR, Silva EL, Pinheiro AL, de Castro-Prado MAA (2014) In vitro genotoxicity of Melaleuca alternifolia essential oil in human lymphocytes. J Ethnopharmacol 151: 852-857.

5. Pazyar N, Yaghoobi R, Bagherani N, Kazerouni A(2013) A review of applications of tea tree oil in dermatology. Inter J Dermatol 52: 784-790.

6. Brophy JJ, Davies NW, Southwell IA, Stiff IA, Williams LR (1989) Gas chromatographic quality control for oil of Melaleuca terpinen4-ol type (Australian tea tree). J Agric Food Chem 37: 1330-1335.

7. Hammer KA, Carson CF, Riley TV (1996) Susceptibility of transient and commensal skin flora to the essential oil of Melaleuca alternifolia (tea tree oil). Am J Infect Control 24: 186-189.
8. Hammer KA, Dry L, Johnson M, Michalak EM, Carson CF, et al. (2003) Susceptibility of oral bacteria to Melaleuca alternifolia (tea tree) oil in vitro. Oral Microbiol. Immunol 18: 389-392.

9. Banes-Marshall L, Cawley P, Phillips CA (2001) In vitro activity of Melaleuca alternifolia (tea tree) oil against bacterial and Candida spp. isolates from clinical specimens. Br J Biomed Sci 58: 139-145.

10. Andrade BFMT, Barbosa LN, Alves FCB, Albano M, Rall VLM, et al. (2016) The antibacterial effects of Melaleuca alternifolia, Pelargonium graveolens and Cymbopogon martinii essential oils and major compounds on liquid and vapor phase. J Essential Oil Res 28: 227-233.

11. Cox SD, Mann CM, Markham JL, Bell HC, Gustafson JE, et al. (2000) The mode of antimicrobial action of the essential oil of Melaleuca alternifolia (tea tree oil). J Appl Microbiol 88: 170-175.

12. Reichling J, Weseler A, Landvatter U, Saller R (2002) Bioactive essential oils used in phytomedicine as antiinfective agents: Australian tea tree oil and manuka oil. Acta Phytotherapeutica 1: 26-32.

13. Carson CF, Mee BJ, Riley TV (2002) Mechanism of action of Melaleuca alternifolia (tea tree) oil on Staphylococcus aureus determined by timekill, lysis, leakage, and salt tolerance assays and electron microscopy. Antimicrob Agents Chemother 48: 1914-1920.

14. Walsh LJ, Longstaff J (1987) The antimicrobial effects of an essential oil on selected oral pathogens. Periodontology 8: 11-15.

15. Elsom GKF, Hide D (1999) Susceptibility of methicillin-resistant Staphylococcus aureus to tea tree oil and mupirocin. J Antimicrob Chemother 43: 427-428.

16. Inouye S, Takizawa T, Yamaguchi H (2001) Antibacterial activity of essential oils and their major constituents against respiratory tract pathogens by gaseous contact. J Antimicrob Chemother 47: 565-573.

17. Falci SP, Teixeira MA, Chagas PF, Martinez BB, Loyola AB, et al. (2015) Antimicrobial activity of Melaleuca sp. oil against clinical isolates of antibiotics resistant Staphylococcus aureus. Acta Cirurgica Brasileira 30: 401-406.

18. (2015) National Action Plan for Combating Antibiotic-Resistant Bacteria (NAPCARB).

19. Eric Z (2016) Replacing antibiotics with tea tree oil.

20. Singh BR (2009) Labtop for Microbiology Laboratory, 2009. Lambert Academic Publishing, AG \& Co. KG, Berlin, Germany.

21. Singh BR (2013) Evaluation of antibacterial activity of sage (Salvia officinalis) oil on veterinary clinical isolates of bacteria.

22. Singh BR (2013) Antimicrobial sensitivity assay and antimicrobial chemotherapy in Animals: A practical approach. In: Singh BR, Somvanshi R (eds.) Diseases of animals: Diagnosis and management. ICAR-Indian Veterinary Research Institute, Izatnagar, pp: 7-31.

23. Singh BR, Singh RK, Singh V (2015). Aerobic mesophilic bacterial flora of vagina of healthy Mithun (Bos frontalis). J Genital System Disord 3: 1-7.

24. Singh BR (2014) Multiple-herbal-antimicrobial-resistance (MHAR) in microbes of animals, birds, fish, food, lizard and water origin. In: Proceedings of International conference and 28th Annual convention of IAVMI-2014 on "Challenges and Opportunities in Animal Health at the Face of Globalization and Climate Change".

25. Singh BR, Siddiqui MZ (2015) Antimicrobial activity of Commiphora wightii gum (Guggul gum) extract against gram positive and gram negative bacteria. J Microbiol Antimicrob Agents 1: 36-39.

26. Singh BR, Agrawal RK, Sinha DK, Vinodh OR, Vadhana P, et al. (2015) Antimicrobial activity in aqueous and methanolic leaf extract of Eupatorium odoratum against bacteria of clinical and nonclinical origin. J Ad Clinl Pharmacol 2: 50-59.

27. Singh BR, Agrawal RK, Vadhana P, Bhardwaj M, Dubey S (2015) Antimicrobial activity of citronella essential oil on antimicrobial drug resistant bacteria from veterinary clinical cases. Clin Med Biochem.

28. Singh BR, Agrawal RK, Dubey S, Bhardwaj M, Vadhana P (2015) Antimicrobial activity of Rose Geranium (Pelargonium roseum) essential oil on bacteria of veterinary clinical origin. Asian J Pharmaceut Technol Innovation 3: 1-5. 
Citation: Singh BR, Vadhana P, Bhardwaj M, Vinodh Kumar OR, Sinha DK, et al. (2016) Comparative Antimicrobial Activity of Tea Tree Oil (Melaleuca Oil) and Common Topical Antimicrobials against Bacteria Associated With Wound and Topical Infections. Pharm Anal Acta 7: 513. doi:10.4172/2153-2435.1000513

Page 9 of 9

29. Vadhana P, Singh BR, Bhardwaj M, Singh SV (2015) Emergence of Herbal Antimicrobial Drug Resistance in Clinical Bacterial Isolates. Pharm Anal Acta 6: 434.

30. Normark BH, Normark S (2002) Evolution and spread of antibiotic resistance. J Int Med 252: 91-106.
31. Kumar S, Singh BR (2013) An Overview on Mechanisms and Emergence of Antimicrobials Drug Resistance. Adv Anim Vet Sci 1: 7-14.

32. (2016) National Treatment Guidelines for Antimicrobial Use in Infectious Diseases (NTGA). 